\begin{tabular}{|c|c|c|c|c|c|c|}
\hline \multirow{4}{*}{ Impact Factor: } & ISRA (India) & $=4.971$ & SIS (USA) & $=0.912$ & ICV (Poland) & $=6.630$ \\
\hline & ISI (Dubai, UAE & $=0.829$ & РИНЦ (Russia) & $=0.126$ & PIF (India) & $=1.940$ \\
\hline & GIF (Australia) & $=0.564$ & ESJI (KZ) & $=8.716$ & IBI (India) & $=4.260$ \\
\hline & JIF & $=1.500$ & SJIF (Morocco) & $=5.667$ & OAJI (USA) & $=0.350$ \\
\hline
\end{tabular}

\section{SOI: $\underline{1.1 / \text { TAS }}$ DOI: $10.15863 /$ TAS \\ International Scientific Journal Theoretical \& Applied Science}

\author{
p-ISSN: 2308-4944 (print) e-ISSN: 2409-0085 (online) \\ Year: $2020 \quad$ Issue: 03 Volume: 83
}

Published: 30.03 .2020

http://T-Science.org
QR - Issue

QR - Article
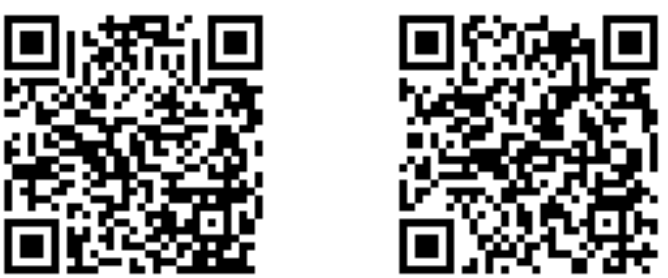

Sherzod Uktamovich Azizov

Institute of Customs, State Customs Committee Doctor of Science, associate professor,

Republic of Uzbekistan

\title{
IS IT OBJECTIVE OR A LIFE NEED TO INTRODUCE CUSTOMS AUDIT IN UZBEKISTAN ?!: THEORETICAL BASIS AND PRACTICAL EXPERIENCES
}

\begin{abstract}
Further simplification of customs control and clearance processes for imported goods and vehicles, reduction of time and money spent on them are recognized not only in the customs authorities of Uzbekistan, but also in the rules of the World Customs Organization as the main indicators of foreign trade efficiency. Given that the improvement of these indicators can be achieved through the introduction of post-export customs audit, this article highlights the objective need for the introduction of customs audit in the customs system of the country and its vital need. The author also comments on the adoption of a regulatory framework for the organization and conduct of customs audit in the system, the processes associated with the definition of priorities in this regard.

Key words: financial control, customs control, audit activity, audit, customs audit.

Language: English

Citation: Azizov, S. U. (2020). Is it objective or a life need to introduce customs audit in Uzbekistan ?!: Theoretical basis and practical experiences. ISJ Theoretical \& Applied Science, 03 (83), 278-282.

Soi: http://s-o-i.org/1.1/TAS-03-83-53 Doi: crossef https://dx.doi.org/10.15863/TAS.2020.03.83.53

Scopus ASCC: 2000.
\end{abstract}

\section{Introduction}

It is gratifying that the prudent policy pursued by the President of our country Sh. Mirziyoyev in all spheres and industries and the large-scale reforms being carried out also cover the customs system. However, "... complex procedures and lengthy customs control and clearance procedures, corruption offenses and abuse of power among customs officials continue to hamper the full implementation of reforms." [1].

It should be noted that from the beginning of this year to date, a number of normative and legal documents on customs activities, State Programs, Road Maps, Action Plan - the development of customs procedures in the field of customs control and clearance. ) It is not difficult to understand that further simplification in the short term is a vital need for them to serve to increase the efficiency of the system. In particular, the following normative legal acts, the tasks and responsibilities set out in them clearly prove this:

1. "Five priorities for the development of the Republic of Uzbekistan in 2017-2021" approved by the President of the Republic of Uzbekistan on March 2, 2020, consisting of 284 items, providing for the implementation of projects worth 18.1 trillion soums and 10.3 billion US dollars. Decree PF-5953 "On the State Program for the Implementation of the Action Strategy in the Year of Science, Enlightenment and Digital Economy" is a very important task for the customs system, which is both pending and prioritized. the need to address the issues.

2. 2020 of the State Customs Committee of the Republic of Uzbekistan No. 43 of March 9, "President of the Republic of Uzbekistan 2020 On the implementation of the Decree No. PF-5953 of March 2, "Paragraph 4" and its appendix "Program of measures to be implemented by the State Customs Committee" was approved. It was noted that in the framework of the program "Improving the efficiency of customs administration" will be developed draft decrees and resolutions of the President of the Republic of Uzbekistan on "Introduction of the Institute of Customs Audit."

3. By the Deputy Prime Minister of the Republic of Uzbekistan Approved March 9, 2020, 2020 by SCC 


\begin{tabular}{|c|c|c|c|c|c|c|}
\hline \multirow{4}{*}{ Impact Factor: } & ISRA (India) & $=4.971$ & SIS (USA) & $=0.912$ & ICV (Poland) & $=6.630$ \\
\hline & ISI (Dubai, UAE & $=0.829$ & РИНЦ (Russia & $=0.126$ & PIF (India) & $=1.940$ \\
\hline & GIF (Australia) & $=0.564$ & ESJI (KZ) & $=8.716$ & IBI (India) & $=4.260$ \\
\hline & JIF & $=1.500$ & SJIF (Morocec & $=5.667$ & OAJI (USA) & $=0.350$ \\
\hline
\end{tabular}

In accordance with paragraph 8 of the "Roadmap for the main activities of the WBC in 2020", registered and adopted on March 11, No. R-01-1 / 1-022, and by the WBC on March 11, 2020 Short-term and longterm Action Plan of the Republic of Uzbekistan, registered under R-01-1 / 1-023 Item 2 "Control over the management of foreign economic activity by notarial methods and for the purpose of analysis of import and export operations and in the system of customs authorities as a form of customs control after the release of goods. Develop a draft of the relevant normative legal act, which defines the procedures for establishing a separate structural unit within the Customs Committee, submission to the Cabinet of Ministers in accordance with the established procedure ", "Organization of a training seminar on the basis and requirements of customs audit".

4. Approved by the Chairman of the State Customs Committee of the Republic of Uzbekistan on February 12, 2020, by the State Customs Committee for 2020. In the work plan of the Cabinet of Ministers of the Republic of Uzbekistan for the 1st half of 2020, registered and adopted on February 14, No. R-01-1 / 1-015, paragraph 25 of the Program of comprehensive measures to ensure the implementation of tasks assigned to the State Customs Committee control over the management of activities by notarial methods as well as the analysis of import and export operations and customs audit after the release of goods as a form of customs control "in the 1st quarter of 2020 within the State Customs Committee of the Republic of Uzbekistan new structures for control over foreign economic activity and customs audit implementation of the establishment mechanism. In addition, paragraph 32 of the program states that "the International Convention on the Simplification and Harmonization of Customs Procedures (Kyoto, 1973) In May 2020, it is planned to take the necessary measures to bring the legislation of the Republic of Uzbekistan in line with the requirements of this Convention.

In short, the above-mentioned normative and legal documents, along with the establishment of a humane democratic rule of law in Uzbekistan, ensuring international economic integration, further support of entrepreneurs, providing them with a favorable business environment and the necessary conditions for effective operation, to develop The issues of creating a solid foundation for bright development in the future of our country are reflected in detail in the system, which must be addressed, the necessary priorities. This, in turn, makes it an objective necessity to introduce one of the new forms of state financial control in the customs system today, including customs audit, or the fact that it is a vital necessity. Today, every individual operating in any space is realizing his rights, duties and freedoms more fully and deeply, their consciousness and thinking are changing and their worldview is developing. In particular, today's FEA participant is aware of the latest developments in the customs legislation of the developed countries of the world, reads and masters, has a unique knowledge of the conditions created for FEA participants, and is far ahead of customs officials in thinking. Their views and comments aimed at understanding the meaning of the word control at customs posts now require that it be considered not only unilaterally, but equally in terms of the interests of all parties, ie the state, society and consumers. Therefore, it is a great professional skill of the customs officer to achieve full, timely and fair collection of customs duties from the budget without spending their extra time and money, while agreeing with the system to provide quality and additional customs services to foreign trade entities subject to customs control. requires dedication.

I believe that ensuring the speedy and highquality implementation of these tasks and tasks set by the system will give a positive result and will be the first step towards further development of customs administration.

\section{LITERATURE REVIEW}

Today, the issue of further simplification of procedures related to customs control and clearance has become a top priority of customs administration around the world. Especially in the current conditions of Uzbekistan, further simplification of customs control at customs posts, optimization of its conditions and principles is changing for the better.Selection using the risk management system, which has been introduced without the old $100 \%$, inspections based on gross customs control, requires the application of post-release customs audit. These cases, in turn, require answers to questions about how, on what basis and by what means to conduct a customs audit.

In our opinion, it is necessary to pay attention to the views of practitioners and economists on the content of the concept of customs audit in the member states of the World Trade Organization or the Eurasian Economic Union or non-member countries, observer status in the CIS. In particular, D.L. Tukeev, L.D. Salakova from the Russian Federation [3] to the customs audit: "Analyzing the foreign experience of customs control after the release of goods, this form of control in the form of customs audit in foreign countries, less or more than customs duties It is an activity aimed at detecting and eliminating violations in the field of customs, "said a group of researchers AA Berzan, O.E. Kudryavtsev, V.V.Solovev, I.V.Soloveva, E.P. Luneva, L.A.Popova, S.A.Chepurnov [4], "Customs audit is a type of state control carried out by the customs authorities after the release of goods." S.N.Shostak [5] and A.S.Shvets [6] also recognize that "customs audit is a type of independent activity carried out by private audit organizations on a business basis."

The practical experience of developed countries 


\begin{tabular}{|c|c|c|c|c|c|c|}
\hline \multirow{4}{*}{ Impact Factor: } & ISRA (India) & $=4.971$ & SIS (USA) & $=0.912$ & ICV (Poland) & $=6.630$ \\
\hline & ISI (Dubai, UAE & $=0.829$ & РИНЦ (Russia & $=0.126$ & PIF (India) & $=1.940$ \\
\hline & GIF (Australia) & $=0.564$ & ESJI (KZ) & $=8.716$ & IBI (India) & $=4.260$ \\
\hline & JIF & $=1.500$ & SJIF (Morocce & $=5.667$ & OAJI (USA) & $=0.350$ \\
\hline
\end{tabular}

shows that the introduction of a customs audit mechanism in the customs system is a preventive measure aimed at idenFEAying, preventing and eliminating inconsistencies in the financial accounting and reporting data of FEA entities on foreign trade activities; a means of harmonizing the provisions of domestic regulations on procedures related to customs control and clearance with the standard requirements of international conventions (agreements, notes, resolutions, directives, memoranda); Teaching FEA subjects to respect customs legislation through the application of more simplified customs procedures to honest FEA entities, clarifying the criteria for granting incentives and preferences to encourage them, is recognized as an additional criterion for assessing the increase in state budget revenues. It should be noted that in this regard, the main priority for the Association of Customs Auditors and Consultants, established in 2016 as a non-governmental organization in the Russian Federation in order to implement the "Targets for the development of the customs service of the Russian Federation until 2030." and the application of advanced customs audit techniques "[7]. To this association:

development of normative and legal documents on customs audit (Regulations, standards, guidelines); organization of professional training and advanced training courses in the field of customs audit; audit;

improvement of methods and forms of customs

to obtain the right to advance to the next stage of the status of authorized economic operators.

\section{ANALYSIS AND RESULTS}

In our country, great attention is paid to improving the efficiency and effectiveness of the use of budget funds. In this regard, the President of the Republic of Uzbekistan Sh. Mirziyoyev said: "The need to further strengthen control over the targeted and rational use of budget funds, In addition, the Cabinet of Ministers will be tasked with drafting laws on public financial control and public debt, improving the system of control over foreign trade and improving infrastructure, with the involvement of international experts within three months. It is not in vain that they recognize the need to reform the activities of the customs, sanitary, quarantine, veterinary and other agencies that exercise control at customs posts "[2].

It should be noted that the main purpose of the customs service is to ensure the economic security of the country and the formation of state budget revenues. (Table 1 ).

Table-1. Transferred to the state budget by the customs authorities structure of customs duties [8] (billion soums)

\begin{tabular}{|c|c|c|c|c|c|c|}
\hline Type of payment & $\mathbf{2 0 1 7 - y}$ & Portion, \% & $\mathbf{2 0 1 8 - y .}$ & Portion, \% & $\mathbf{2 0 1 9 - y . ~}$ & Portion, \% \\
\hline Import fee & 1780,54 & 22,32 & 1826,43 & 15,90 & 2302,69 & 13,4 \\
\hline Excise tax & 1039,36 & 13,04 & 514,79 & 4,48 & 818,50 & 4,8 \\
\hline AVT & 4877,47 & 61,15 & 8775,97 & 76,40 & 13397,68 & 78,3 \\
\hline Customs duties & 278,55 & 3,49 & 370,00 & 3,22 & 609,22 & 3,5 \\
\hline Total & $\mathbf{7 9 7 5 , 9 2}$ & $\mathbf{1 0 0}$ & $\mathbf{1 1 4 8 7 , 1 9}$ & $\mathbf{1 0 0}$ & $\mathbf{1 7 1 2 8 , 0 9}$ & $\mathbf{1 0 0}$ \\
\hline Privileges granted & $\mathbf{2 2 7 6 5 , 5 0}$ & & $\mathbf{4 6 5 0 0 , 1}$ & & $\mathbf{5 6 9 0 0 , 0}$ & \\
\hline
\end{tabular}

The analysis shows that by the end of 2019 , customs duties collected by the customs service to the state budget will reach 17 trillion soums. 128 billion UZS, which is $49.1 \%$ more than in the previous year. Participants in foreign economic activity received 3.3 times more than the total customs duties, ie 39771.91 billion soums. UZS were given privileges. In 2020, a total of 23.3 trillion soums will be submitted to the customs authorities for all types of customs payments. soums for the future plan. According to statistics, in 2019, foreign economic activity entities issued
158,248 customs cargo declarations for export operations and 611,093 customs cargo declarations for import operations [8], ie the volume of imports relative to exports.

More than 3 times means that the application of customs audit in customs practice is an objective necessity. It should be noted that the subjects of foreign economic activity are naturally interested in this customs procedure and have many questions. For example, what form or process of control does this apply to, or who does it, when, in what way, and for 


\begin{tabular}{|c|c|c|c|c|c|c|}
\hline \multirow{4}{*}{ Impact Factor: } & ISRA (India) & $=4.971$ & SIS (USA) & $=0.912$ & ICV (Poland) & $=6.630$ \\
\hline & ISI (Dubai, UAE & $=0.829$ & РИНЦ (Russia & $=0.126$ & PIF (India) & $=1.940$ \\
\hline & GIF (Australia) & $=0.564$ & ESJI (KZ) & $=8.716$ & IBI (India) & $=4.260$ \\
\hline & JIF & $=1.500$ & SJIF (Morocce & $=5.667$ & OAJI (USA) & $=0.350$ \\
\hline
\end{tabular}

how long, and so on? With questions like these, observation can go a long way. Therefore, it is expedient to explain them on a clear scienFEAic basis.

Firstly, customs audit - a new direction of audit, type of service.

Secondly, a separate form of customs control.

Thirdly, the process carried out after the completion of customs clearance of goods and means of transport of foreign economic activity and their release into circulation.

Fourth, according to the data collected on the basis of questionable indicators at the intersection of the corridors through the automated system of risk management, the selected subjects of foreign economic activity are applied to their goods and vehicles.

Fifth, conducted by financial regulators.

Sixth, it is carried out in a planned (mandatory), unscheduled (emergency) and in the form of initiative (according to the application of the subject to the customs authority for a customs privilege (obtaining the status of an authorized economic operator).

Seventh, at least once a year, in respect of 1 formalized CD. In this regard, the previous general customs control was abandoned and the customs control of goods and means of transport was carried out using an automated risk management system through the "yellow", "red", "green" and "blue" corridors, ie the practice of selective inspection of customs control. In particular, if the "green corridor" does not provide for customs control of low-risk goods and vehicles, the "blue corridor" for goods with a medium level of risk or determined on a random basis. It should be noted that the forms of customs control are determined to be carried out after their release, ie through a customs audit"[9].

\section{CONCLUSIONS AND RECOMMENDATIONS}

Based on the results of the analysis of the experience of developed countries [10], the following promising areas of customs audit after the release of goods in the customs system of Uzbekistan were idenFEAied as proposals and recommendations:

1. Reducing the number of customs control measures based on the selection of goods to be released when crossing the border. This, in turn, leads to more efficient use of working time of customs authorities and increase work efficiency. A new form of customs control, based on audit methods, allows a comprehensive analysis of the information required for the calculation of customs payments (customs duties and taxes). To this end, it is permissible to carry out customs clearance measures for FEA entities subject to customs audit at the border customs posts themselves.

2. Audit-based control - is used to confirm that the information in the previously submitted documents on goods and transport is correctly classified according to the TN codes of the goods, to verify the accuracy of the goods in terms of origin and value. In this case, the goods may be released for circulation at once, and customs duties and taxes may be calculated after the customs audit. Otherwise, it is determined to carry out the usual, traditional customs procedures.

3. Customs control based on audit methods shall be carried out periodically (permanent, scheduled) and systematically (regular, emergency, if necessary, when the situation requires) in the form (form). Basically, such inspections are conducted in the territory of the interested party. To do this, the customs authorities study in detail the history of export-import transactions of the FEA subject in a particular period and apply it to a comparative examination of all commercial documents in order to confirm whether the information provided by the declarant is true or not.

Based on the results of the above analysis, suggestions and recommendations, it can be concluded that in order to simplify customs control and customs clearance in Uzbekistan, its new form, post-release customs control - the application of customs audit in practice:

First, raFEAication and implementation of standards 6.4, 6.6 of the International Convention (Kyoto, 1973) in accordance with national legislation;

secondly, the development of an appropriate regulatory framework in line with international standards for its introduction into the practice of the customs system;

thirdly, Due to the fact that one of the main tasks of the customs authorities is to speed up the process and reduce control requirements through regular simplification of customs clearance of imports and exports, the implementation of customs audit as soon as possible and ensure high efficiency.

In addition, one of the main requirements for the membership of states in the Eurasian Economic Union is the introduction of a customs audit (inspection) mechanism in the member states of the Eurasian Economic Union, which is carried out after the release of goods [11].

This means that one of the priorities of the state policy is to improve the current customs system of Uzbekistan. This is done through the indirect application of the mechanism of customs audit in the system in order to create convenience for entrepreneurs in the country (to save time and money spent on customs control and clearance processes) and increase revenues to the state budget. In our opinion, the fairness of customs audit depends on the intelligence, high knowledge, skills and abilities of the subjects, the application of professional skills and best practices, and the creation of new jobs in the new structure, which will provide additional customs services leads to in the near future. Also, in the implementation of the new version of the Customs 


\begin{tabular}{|c|c|c|c|c|c|c|}
\hline \multirow{4}{*}{ Impact Factor: } & ISRA (India) & $=4.971$ & SIS (USA) & $=0.912$ & ICV (Poland) & $=6.630$ \\
\hline & ISI (Dubai, UAE & $=0.829$ & РИНЦ (Russia & $=0.126$ & PIF (India) & $=1.940$ \\
\hline & GIF (Australia) & $=0.564$ & ESJI (KZ) & $=8.716$ & IBI (India) & $=4.260$ \\
\hline & JIF & $=1.500$ & SJIF (Morocce & $=5.667$ & OAJI (USA) & $=0.350$ \\
\hline
\end{tabular}

Code of the Republic of Uzbekistan, based on the requirements of international norms (agreements and conventions) signed with our country bilaterally and multilaterally, to make appropriate amendments and additions to national legislation on the basis of simple, clear and harmonized principles; He has many years of experience in the organization of the customs audit service within the State Customs Committee and the formation of its staff units, the ability to perform financial and statistical (SWOT) analysis and the recruitment of personnel with high economic and legal knowledge, skills and abilities, with the help of which it is desirable to develop and implement customs audit standards using international auditing standards.

In conclusion, the application of customs audit in the practice of the system will accelerate foreign trade operations in the country, increase the state budget revenue by taking preventive measures to train entities not to violate customs legislation, reduce the time spent on customs clearance of foreign trade activities. serve to reduce, increase net profit.

\section{References:}

1. (2018). Decree of the President of the Republic of Uzbekistan No. PF-5414 of April 12, 2018 "On measures to radically improve the activities of the State Customs Service of the Republic of Uzbekistan." Retrieved from https://lex.uz/docs/3680568

2. (2020). Address of the President of the Republic of Uzbekistan Sh. Mirziyoyev to the chambers of the Oliy Majlis. January 24, 2020. Retrieved from http://uza.uz/oz/politics/zbekistonrespublikasi-prezidenti-shavkat-mirziyeevningoliy-25-01-2020

3. Tukeev, D.L., \& Salakova, L.D. (2019). Perspektivy ispolzovaniya v Evraziyskom ekonomicheskom soyuze mejdunarodnogo opyta po osushchestvleniyu tamojennogo kontrolya posle vыpuska tovarov. Ekonomicheskie nauki. Bulletin of Innovative Technologies (BIT) 2019, Volume 3, № 2 (10), 40-44. https://bitjournal.ru/

4. Berzan, A.A. (2007). Development of methodical bases of post-control control. Autoref. dis. k.e.n. 08.00.05 / RTA. (p.15). Moscow.

5. (2005). Posobie / Kudryavtsev O.E., Solovev V.V., Soloveva I.V. (p.97). Rostov-on-Don: RIO Rostov branch RTA.

6. Luneva, E.P. (2003). Methodical and organizational bases of customs audit of exportimport operations of foreign economic activity: Monograph / Under the general edition of Dr. econ. science, professor L.A.Popovoy. (p.7). Moscow: RIO RTA.

7. Popova, L.A., \& Chepurnov, S.A. (2003). Sushchnost, printsipy, zadachi $i$ funktsii tamojennogo audita. Tamojennaya slujba Rossii na zashchite ekonomicheskix interesov strany: Materialy dokladov. (pp. 327-332).
8. Shostak, S.N. (n.d.). Audit: neobxodimoe uslovie uskoreniya i uproshcheniya protsedury tamojennogo oformleniya. Retrieved from http://www.juristic.ru/articles.php?cu=1\&ref=in $\underline{\text { dex }}$

9. Shvets, A.S. (2003). Ekonomicheskaya effektivnost vnedreniya instituta tamojennogo audita $v$ strukturu tamojennyx otnosheniy. Osnovnye aspekty razvitiya tamojennogo dela na sovremennom etape: Sbornik materialov. (p.301).

10. (n.d.). Association of Customs Auditors and Consultants. Official website. Retrieved from https://ataik.ru.

11. (n.d.). Data of the official annual report of the State Customs Committee of the Republic of Uzbekistan.

12. (2018). Decree of the President of the Republic of Uzbekistan No. PF-5582 of November 24, 2018 "On additional measures to improve the customs administration and increase the efficiency of the State Customs Service of the Republic of Uzbekistan." Retrieved from https://lex.uz/docs/4076899.

13. Tivikova, M.S. (n.d.). Zarubejnyy opyt tamojennogo kontrolya posle vipuska tovarov. Retrieved from https://studylib.ru/doc/2201119/udk-338.465m.-s.-tivikova-zarubezhnyj-opyttamozhennogo-ko...

14. (n.d.). "Customs Code of the Eurasian Economic Union” (application №1 to the Treaty on the Customs Code of the Eurasian Economic Union).

http://www.consultant.ru/document/cons_doc LAW_215315/c1360fe021e657bc0433cc3d060 551597baeb4aa/ 